\title{
PENCALONAN MANTAN NARAPIDANA SEBAGAI ANGGOTA LEGISLATIF PERSPEKTIF FIKIH SIVÂSAH
}

\author{
Musyafiatun \\ Perumahan Nasional Siliragung Blok a5 00 I6/00 I Silliragung Banyuwangi | \\ Sofi86hadi@gmail.com
}

\begin{abstract}
This article focuses on the Islamic political jurisprudence perspective against the decision of the Constitutional Court (MK) No. 4/PUU-VII/2009 on the nomination of an ex of a prisoner as a legislator. MK's decision allows the ex of a prisoner to become a legislator, DPD, and local leader with certain conditions. The basic of the consideration is that the Constitutional Court has the authority to examine, hear, and decide the decision No. 4/PUU-VII/2009. In addition, the applicant also has no legal status in this respect (legal standing) and consideration of the principal arguments of the applicant's request. MK's decision No. 4/PUU-VII/2009 has juridical implication on article 12 letter $g$ and article 50 paragraph ( I ) letter g of Law No. 10/2008 and article 58 letter $f$ of Law No. 12/2008 as well as the political implications on the opportunities for the ex of a prisoner to hold a public office. Based on the Islamic political jurisprudence perspective, MK's decision No. 4/PUU-VII/2009, which permitted the ex of a prisoner as a legislator, DPD and local leader with certain conditions, is in line with the concept of constitutional politics that includes the rights of the people. It is because the ex of a prisoner is also a member of the community whose rights should be protected if he or she repents.
\end{abstract}

Keywords: Nominations, prisoner, members of the legislature.

Abstrak: Artikel ini tinjauan fiqh siyasah terhadap Putusan MK No.4/PUU-VII/2009 tentang pencalonan narapidana sebagai anggota legislatif. Putusan MK No.4/PUU-VII/2009 memperbolehkan mantan narapidana sebagai anggota legislatif, DPD dan kepala daerah dengan syarat-syarat tertentu. Dasar pertimbangannya adalah bahwa Mahkamah Konstitusi mempunyai wewenang untuk menguji, mengadili dan memutus perkara No.4/PUU-VII/2009, selain itu 
pemohon juga mempunyai kedudukan hukum dalam hal ini (legal standing) dan pertimbangan pada pokok permohonan dalil-dalil pemohon. Putusan MK No.4/PUU-VII/2009 berimplikasi pada posisi yuridis pasal 12 huruf $g$ dan pasal 50 ayat (I) huruf g UU No. 10/ 2008 dan pasal 58 huruf f UU No. 12/ 2008 serta berimplikasi pada aspek politik yakni membuka kesempatan bagi mantan narapidana untuk dapat menduduki jabatan publik yang dipilih (elected officials). Berdasarkan kajian fiqih siyasah Putusan MK No.4/PUU-VII/2009 yang memperbolehkan mantan narapidana sebagai anggota legislatif, DPD dan kepala daerah dengan syarat-syarat tertentu adalah sejalan dengan konsep siyasah dusturiyah yang mencakup hak-hak umat, sebab mantan narapidana juga termasuk umat dalam negara Islam, yang harus dilindungi hak-haknya apabila bertaubat.

Kata Kunci: Pencalonan, narapidana, anggota legislatif.

\section{Pendahuluan}

Dalam sistem ketatanegaraan Indonesia, terdapat tiga kekuasaan yaitu legislatif, eksekutif, dan yudikatif, yang ketiganya biasa disebut dengan trias politika.

Badan legislatif adalah lembaga yang legislate atau membuat undang-undang. Nama lain yang sering dipakai adalah parlemen. ${ }^{1}$ Dalam sistem ketatanegaraan, badan legislatif meliputi MPR, DPR, DPD, dan DPRD, Yang semuanya mempunyai tugas, fungsi dan wewenang masing-masing. Mereka mempunyai peranan yang bertujuan melaksanakan fungsi perwakilan, perundang-undangan dan pengawasan.

Kekuasaan eksekutif adalah kekuasaan negara yang melaksanakan undang-undang, menyelenggarakan urusan pemerintahan dan mempertahankan tata tertib dan keamanan baik di dalam maupun di luar negeri. ${ }^{2}$

Kekuasaan eksekutif biasanya dipegang oleh badan atau lembaga eksekutif. Di negara demokratis, badan eksekutif biasanya terdiri dari kepala negara seperti raja atau presiden

\footnotetext{
' Miriam Budiarjo, Dasar-Dasar Ilmu Politik, (Jakarta: Gramedia Pustaka Utama, 2004), 173

2 Titik Triwulan Tutik, Pokok-Pokok Hukum Tata Negara Pasca Amandemen UUD 1945, (Jakarta: Prestasi Pustaka, 2006), 142
}

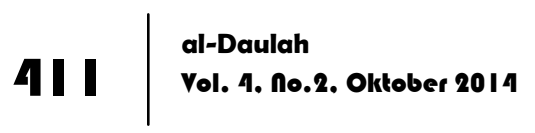


bersama menteri-menterinya. Badan eksekutif yang luas mencakup para pegawai sipil dan militer. ${ }^{3}$

Sedangkan kekuasaan yudikatif merupakan kekuasaan mengadili yang dibagi menjadi tiga kamar yakni; Mahkamah Agung (MA), Mahkamah Konstitusi (MK), dan Komisi Yudisial $(\mathrm{KY}){ }^{4}$

Berdasarkan uraian di atas, ketiga kekuasaan tersebut mempunyai tugas, fungsi dan wewenang yang berbeda-beda. Selain itu untuk menjadi pejabat dalam lembaga-lembaga di atas harus memenuhi syarat yang ditetapkan oleh undang-undang yang telah disesuaikan dengan karakter jabatan masing-masing. Seperti presiden, menteri, DPR, hakim dan lain-lain.

Negara Indonesia adalah negara kesatuan yakni kekuasaannya terdiri dari pemerintahan pusat dan pemerintahan daerah. Pemerintahan pusat merupakan kekuasaan yang menonjol dalam negara dan tidak ada saingannya dari badan legislatif pusat dalam membentuk undang-undang. ${ }^{5}$

Dalam UU RI No. 32 Tahun 2004 tentang Pemerintah Daerah, menyebutkan bahwa:

"Pemerintahan daerah adalah penyelenggaraan rumusan pemerintahan oleh pemerintahan daerah dan DPRD menurut asas otonomi seluas-luasnya dalam sistem dan prinsip Negara Kesatuan Republik Indonesia sebagai dimaksud dalam UUD negara Indonesia Tahun 1945."6

Sedangkan pemerintah daerah adalah kepala daerah dan dewan perwakilan rakyak daerah. Kepala daerah memimpin badan eksekutif dan DPRD bergerak dalam bidang legislatif. Kepala daerah (residen, bupati dan walikota) adalah pejabat pemerintahan yang diangkat oleh pemerintahan pusat. Mereka masing-masing menurut berbagai peraturan yang berlaku

\footnotetext{
${ }^{3}$ Miriam Budiarjo, Dasar-Dasar Ilmu Politik, 208

${ }^{4}$ Titik Triwulan Tutik, Pokok-Pokok Hukum Tata Negara, 247

${ }^{5}$ Ibid., 283

${ }^{6}$ Pasal I ayat 2 UU RI No. 32 Tahun 2004 Tentang Pemda.
} 
mempunyai tugas menjalankan wewenang pemerintah pusat di lingkungan wilayah jabatannya. ${ }^{7}$

Kepala daerah mempunyai dua fungsi yaitu sebagai kepala daerah otonom yang memimpin penyelenggaraan dan bertanggungjawab sepenuhnya tentang jalannya pemerintahan daerah dan fungsi sebagai kepala wilayah yang memimpin penyelenggaraan urusan pemerintahan umum menjadi tugas pemerintahan pusat di daerah. ${ }^{8}$

Dengan demikian antara lembaga legislatif dengan kepala daerah sebagai badan eksekutif mepunyai hubungan kerja dalam merumuskan kebijaksanaan dalam rangka menjalankan roda pemerintahan. Di antara keduanya mempunyai tugas dan fungsi yang berbeda. Akan tetapi setiap pelaksanaan kegiatan dan pembangunan haruslah merupakan suatu kebulatan yang utuh dalam rangka pemenuhan kebutuhan masyarakat dan terbina kestabilan keamanan dan ketertiban masyarakat dalam arti luas. Oleh karena itu antara legislatif dan eksekutif sebagai unsur pemerintahan, perlu dijalin hubungan kerja sama yang baik demi kepentingan bangsa.

Dalam proses dan kegiatan memilih pejabat publik dalam pemerintahan, dilakukan dengan cara pemilihan umum yang melibatkan seluruh rakyat untuk menentukan siapa yang berhak menjadi pejabat publik dalam pemerintahan. Pemilihan ini biasanya disebut pemilihan umum atau pemilu.

Pemilu merupakan bagian dari proses rakyat yang memilih pemimpin negara. ${ }^{9}$ Selain memilih kepala negara sebagai lembaga eksekutif juga memilih DPR sebagai lembaga legislatif dan kepala daerah sebagai eksekutif daerah.

Pada sistem politik telah merubah cara pemilihan umum anggota legislatif dan eksekutif yang semula secara perwakilan

\footnotetext{
${ }^{7}$ Titik Triwulan Tutik, Pokok-pokok Hukum Tata Negara, 191

${ }^{8}$ BN. Marbun, DPRD: Pertumbuhan, Masalah dan Masa Depannya., (Jakarta: Erlangga, 1994), 48

${ }^{9}$ Ipong S.Azhar, Benarkah PPK Mandul: Pemilu, Parpol dan DPR Masa Orde Baru, (Yogyakarta: Bigraf Pub., 1997), 5
} 
akhirnya dilakukan secara langsung. Ini berarti Indonesia telah melaksanakan demokratisasi.

Agar dapat diikutkan dalam pemilihan, maka harus mencalonkan diri ke KPU dengan syarat-syarat atau kriteriakriteria yang telah ditentukan oleh undang-undang. Akan tetapi banyak calon yang dikeluarkan dari daftar pemilihan, karena salah satu syarat yang tidak dipenuhi yaitu syarat tidak pernah dijatuhi hukuman pidana penjara berdasarkan putusan pengadilan yang telah mempunyai kekuatan hukum tetap karana melakukan tindak pidana yang diancam dengan pidana penjara lima tahun atau lebih.

Dengan adanya syarat tersebut banyak calon yang merasa dirugikan oleh undang-undang tersebut. Calon yang merasa dirugikan itu adalah seorang warga negara Indonesia yang ingin mencalonkan diri sebagai calon legislatif dalam pemilu 2009, dia bernama Robertus Adji. Karena merasa undang-undang berlaku tidak adil pada mantan napi, maka dilakukan uji materi terhadap undang-undang tersebut ke Mahkamah Konstitusi.

Pemohon pada uji materi ini adalah Robertus, calon legislator untuk DPRD kabupaten Lahat Sumatra Selatan dari PDI Perjuangan yang gagal karena terganjal kasus pidana. Ia gagal menjadi caleg, karena pernah dipidana selama 9 Tahun karena kasus penyimpanan senjata api, perampokan dan penganiayaan berat pada tahun 1976 silam. ${ }^{10}$

Undang-undang yang diajukan ke Mahkamah Konstitusi untuk diuji materi adalah UU No. 10 Tahun 2008 tentang pemilu DPR , DPD dan DPRD pasal 12 huruf g pasal 50 ayat 1 UU No. 12 Tahun 2008 tentang Pemda, pasal 58 huruf f. Menurut pemohon undang-undang tersebut tidak memberikan kesempatan kepada mantan narapidana untuk menduduki jabatan lagislatif dan kepala daerah.

10 Mantan Narapidana Jadi Caleg, http://mediaindonesia.com. Selasa, 24 Maret 2009.

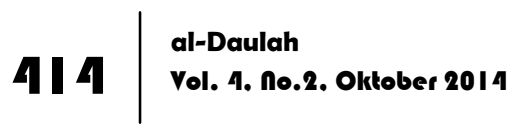


Dita Indah Sari menyebut DPR telah bertindak diskriminatif. Menurut dia hak-hak politik mantan narapidana yang telah menjalani hukuman seharusnya dipulihkan kembali. ${ }^{11}$ Sedangkan menurut pakar hukum Universitas Indonesia, Rudi Satriyo Mukantarjo, menilai rumusan yang dihasilkan DPR masih kurang tepat. " Mestinya bukan tidak pernah atau sedang menjalani pidana penjara, tapi sama sekali tidak terlibat dalam kasus pidana ". ${ }^{12}$ Selain itu banyak kalangan masyarakat yang menganggap UU tersebut telah merugikan hak Konstitusional, karena masih memposisikan para terpidana sebagai warga kelas dua karena tidak diberikan kedudukan hukum yang sama. Padahal pada UUD 1945 pasal 27 (1) menyebutkan bahwa "Segala warga negara bersamaan kedudukannya di dalam hukum dan pemerintahan dan wajib menjunjung hukum dan pemerintahan itu dengan tidak ada kecualinya" 13

Berarti pasal tersebut menjelaskan setiap warga negara Indonesia mempunyai hak asasi untuk mendapatkan perlakuan yang sama dalam hukum, pemerintahan dan hak politik. Yakni hak untuk ikut serta dalam pemerintahan, hak pilih (memilih dan dipilih) dalam pemilihan umum. Jadi setiap warga negara Indonesia berhak untuk memilih dan diplih tanpa ada pengecualian.

Dengan alasan dan berbagai pertimbangan hukum akhirnya Mahkamah Konstitusi mengabulkan bersyarat permohonan pengujian pasal 12 huruf g, pasal 50 ayat (1) UU No. 10 Tahun 2008 Tentang Pemilu DPR, DPD dan DPRD, dan pasal 58 huruf f UU No. 12 Tahun 2008 Tentang Pemerintah Daerah, dengan putusan MK NO.4/PUU-VII/2009.

Dengan adanya keputusan tersebut maka peluang mantan narapidana untuk mengikuti perebutan kursi Dewan Perwakilan Rakyat, menjadi calon Presiden atau Wakil Presiden serta Kepala

\footnotetext{
II Aspek hukum, www.hukumonline.com. Kamis, 7 September 2007.

12 lbid.

13 UUD 1945.
} 
Daerah terbuka lebar. ${ }^{14}$ Sekarang Robertus bisa bernafas lega karena upayanya berhasil dalam memperjuangkan hak mantan narapidana untuk ikut andil dalam pemerintahan.

\section{Pencalonan Narapidana sebagai Anggota Legislatif}

Sebelum penulis menyelesaikan lebih jauh mengenai latar belakang keputusan MK No.4/PUU-VII/2009, ada baik diuraikan bagaimana kronologi perkara hingga munculnya keputusan tersebut. Mengenai masalah pemilihan calon anggota legislatif dan calon kepala daerah, memang sangat santer dibicarakan dalam pemilihan tahun 2009. Karena calon anggota legislatif dan calon Kepala Daerah disinyalir telah banyak melakukan pelanggaranpelanggaran dalam pemilu.

Dalam pemilu Tahun 2009 ada beberapa calon anggota legislatif dan calon Kepala Daerah yang dikeluarkan dari daftar pemilu karena tidak memenuhi salah satu syarat yang telah ditentukan oleh UU pemilu dan UU Pemda, yaitu: (1) Pasal 12 huruf g UU NO. 10 Tahun 2008 tentang pemilu DPR, DPD, dan DPRD, (2) Pasal 50 ayat 1 huruf g No. 10 Tahun 2008 tentang pemilu DPR, DPD, dan DPRD, (3) Pasal 58 huruf f No.12 Tahun 2008 tentang pemerintahan daerah.

Adapun latar belakang persidangan ini memeriksa perkara No.4/PUU-VII/2009 yang diregistrasi pada hari rabu tanggal 28 Januari 2009. danperkara ini diajukan oleh Robertus yang didampingi oleh empat kuasa hukumnya yaitu 1) Zairin Harahap, SH, MH. 2) Ari Yusuf Amir, SH.MH. 3) Sugito, SH. 4)Ahmad Khairun. H, SH. M.Hum, pemohon merupakan seorang warga negara Indonesia yang hak dan kewenangan konstitusionalnya dirugikan oleh berlakunya Undang-Undang.

Terhadap perkara tersebut, Mahkamah Konstitusi telah menetapkan dengan ketetapan NO.4/PUU-VII/2009, tanggal 24 Maret 2009. Dengan adanya ketentuan yang membatasi berupa

${ }^{14}$ Kompas, Rabu 25 Maret 2009, 2 
persyaratan calon anggota legislatif (DPR, DPD, DPRD) serta calon Kepala Daerah dan Wakil Kepala Daerah bagi mantan terpidana dengan ancaman hukuman 5 (lima) tahun atau lebih jelas-jelas merugikan konstitusional pemohon yang setiap periodesasi ketatanegaraan dengan keadaan normal atau kondisi tertentu akan dilakukan pengisian jabatan tersebut, sehingga hak konstitusional pemohon dapat dipastikan dirugikan dengan adanya persyaratan tersebut.

Dalam penjelasan permohonan, pemohon dalam perkara NO.4/PUU-VII/2009 mengatakan kepada Majelis Hakim Konstitusi dengan menyatakan. Pertama, pasal 12 huruf g dan pasal 50 ayat (1) huruf g UU NO.10 Tahun 2008 tetang pemilu anggota DPR, DPD, dan DPRD serta pasal 58 huruf f UU No.12 Tahun 2008 Tentang Pemda yang kesemuanya mensyaratkan: "tidak pernah dijatuhi pidana penjara berdasarkan putusan pengadilan yang telah mempunyai kekuatan hukum tetap karena melakukan tindak pidana yang diancam dengan pidana penjara 5 (lima) tahun/ lebih."

Pasal-pasal a quo bertentangan dengan UUD 1945 khususnya pasal 1 ayat (2), pasal 27 ayat (1), pasal $28 \mathrm{C}$ ayat (2), pasal $28 \mathrm{D}$ ayat (1) dan ayat (3), dan pasal $28 \mathrm{D}$ ayat (5).

Kedua, menyatakan pasal 12 huruf g dan pasal 50 ayat (1) huruf g UU No.10 Tahun 2008 tentang pemilu anggota DPR, DPD, dan DPRD. Serta pasal 58 huruf f UU No. 12 Tahun 2008 tentang pemda tidak mempunyai kekuatan hukum yang mengikat.

Berikut petikan dalil-dalil hukum yang dikemukakan oleh pemohon: 15

a. Partisipasi politik yang dipersempit dan status mantan narapidana.

1) Bahwa partisipasi masyarakat merupakan aspek penting dalam suatu pemilihan jabatan, baik yang bersifat jabatan publik yang dipilih seperti pemilihan umum anggota DPR, 
DPD, dan DPRD, Kepala Daerah dan Wakil Kepala Daerah serta Presiden dan Wakil Presiden, ataupun jabatan yang diangkat. Sehingga oleh karena harus dibuka seluas-luasnya karena hak masyarakat atas partisipasi masyarakat merupakan bagian dari hak asasi manusia sebagaimana tertuang dalam pasal 27 ayat (1), pasal $28 \mathrm{C}$ ayat (2), pasal 28D ayat (1), pasal $28 \mathrm{D}$ ayat (3) UUD 1945, pasal 21 deklarasi umum hak asasi manusia (UUHAM) PBB Tahun 1948 dan pasal 5 ayat (1), pasal 15, pasal 4 ayat (1) UU No. 39 Tahun 1999 tentang hak asasi manusia.Bahwa dengan demikian partisipasi politik merupakan hak asasi manusia setiap warga negara untuk dapat berpartisipasi dalam kegiatan bersama untuk turut serta menetapkan tujuantujuan dan masa depan negara termasuk menentukan orang-orang yang akan memegang pemerintahan.

2) Bahwa UU pemilu (pasal 12 huruf g dan pasal 50 ayat (1) huruf g) dan UU pemda (pasal 58 huruf f) secara nyata masih membedakan perlakuan terhadap warga negara yang pernah menjalani hukuman dengan warga negara yang tidak pernah dihukum berdasarkan putusan yang telah berkekuatan hukum tetap. Sehingga nampak dengan jelas dan terang di satu sisi pembentuk Undang-Undang menganggap bahwa mantan narapidana adalah orang yang bebas dan bertanggungjawab, dapat aktif dalam pembangunan sebagai warga yang baik dan lain sebagainya namun di sisi lain masih juga menganggap bahwa mantan terpidana adalah orang ang harus dicurigai, tercela, cacat moralnya dan tidak pantas untuk menduduki jabatan public yang dipilih seperti anggota DPR, DPD, dan DPRD. Ataupun kepala daerah dan wakil kepala daerah. Dengan demikian bagaimana mungkin seorang mantan terpidana dapat berperan aktif dalam pembangunan baik formal maupun informal jika negara sendiri telah membatasi ruang gerak atau bahkan membunuh hak-hak politik yang telah 
dimilikinya sejak lahir padahal di satu sisi ia telah membayar lunas semua akibat yang pernah dilakukannya di masa lampau.

3) Bahwa pemohon selain tidak pernah dicabut hak politiknya oleh pengadilan, juga pada prinsipnya telah menjalani hukuman atas tindak pidana yang pernah dilakukannya. Sehingga sudah selayaknya tidak diperlakukan sebagai pendosa seumur hidupnya.

4) Bahwa tujuan dari pembentukan suatu normal UU adalah tercapainya asas kepastian hukum, keadilan dan kemanfaatan. Dengan adanya pasal a quo dalam UU pemilu dan UU pemda maka keadilan yang dicari oleh dan bermanfaat bagi pemohon tidak tercapai.

5) Oleh karenanya pemohon berpendapat bahwa pasal 12 huruf g dan pasal 50 ayat (1) huruf g UU pemilu serta pasal 58 huruf $f$ UU pemda lebih bersifat pengekangan terhadap hak-hak politik warga negara dan melanggar hak asasi manusia sebagaimana di jamin oleh UUD 1945, pasal 27 ayat (1) , asal 28 C ayat (1), pasal 28 D ayat (1), dan ayat (1), serta pasal 21 DUHAM PBB 1948.

b. Penghukuman dan stigmatisasi seumur hidup

1) Bahwa setiap warga negara yang telah menjalani pidana penjara berdasarkan putusan pengadilan yang telah berkekuatan hukum tetap sama artinya dengan warga negara lainnya yang dilahirkan dalam keadaan bersih, bebas, berharkat, dan bermartabat serta sederajat di mata hukum.

2) Bahwa adanya persyaratan sebagaimana yang tersebut dalam pasal 12 huruf g dan pasal 50 ayat (1) huruf g UU pemilu, serta pasal 58 huruf $\mathrm{f}$ UU pemda tidak dapat menjamin atau menghasilkan calon yang lebih berkualitas dan memiliki integritas lebih baik dibanding dengan orang yang pernah menjalani masa hukuman pidana dengan ancaman hukuman 5 (lima) Tahun atau lebih. Bahkan 
sebaliknya, sejarah pun telah membuktikan bahwa orang yang pernah dihukum atau dipidana pun dapat berinteraksi, bergaul, dan diterima masyarakatnya sampai pada dipilih dipercaya dan menjadi pemimpin bagi mereka seperti yang pernah dialami oleh Bung Karno dan A.M.Fatwa.

3) Bahwa pasal-pasal a quo salain telah menghukum menghapus hak politik mantan terpidana juga telah menstigma memberi label mantan terpidana sebagai individu yang berbeda dengan individu lainnya yang tidak pernah dipidana, sehingga tidak mendudukannya secara sama di dalam hukum yang pada akhirnya berimbas pula kepada perlakuan yang tidak sama dihadapan hukum dan pemerintahan.

c. Inkonsistensi pembentuk Undang-Undang dan diskriminasi

1) Bahwa ketentuan pasal 12 huruf g dan pasal 50 ayat (1) huruf g UU pemilu, serta pasal 58 huruf f UU Pemda selain telah membunuh hak politik dan bersifat diskriminatif juga telah nyata merupakan bentuk dari tidak konsistennya pembentuk UU dalam menerapkan persyaratan-persyaratan untuk suatu jabatan publik.

2) Bahwa telah nyata ketentuan pasal 12 huruf g dan pasal 50 ayat (4) huruf g UU pemilu, serta pasal 58 huruf f UU pemda meruakan pula dan bentuk diskriminatif dan bertentangan dengan nilai-nilai asasi dari hak dasar manusia yang pada pokoknya merupakan pembatasan hak fundamental dan inkonstitusional.

3) Bahwa dengan lahirnya pasal-pasal a quo selain menimbulkan sikap diskriminasi, melanggar hak asasi dan hak keperdataan warga negara juga bukanlah UU pembuatan yang adil, yang dapat menjamin pengkuan dan penghormatan atas hak asasi manusia, nilai-nilai agama dan ketertiban umum dalam suatu masyarakat demokratis 
sebagaimana yang diperintahkan oleh UUD 1945, khususnya pasal 28 I ayat (5).

d. Pemilu sebagai perwujudan kedaulatan rakyat

1) Bahwa pasal 1 ayat (2) UUD 1945 menegaskan kedaulatan tertinggi berada di tangan rakyat dan prinsip kedaulatan rakyat merupakan prinsip konstitusi yang sangat mendasar dan tidak dapat dikesampingkan.

2) Bahwa hal yang aneh dan tidak berdasar jika negara menghapus hak dipilih mantan terpidana sedang hak memilihnya tidak dihapus, dan lebih aneh dan tidak berdasar lagi jika hak pilih tersebut dihapus tanpa ada kesalahan yang diperbuatnya. Bukankah perbuatan pidana yang pernah dilakukannya telah mendapat penghukuman tersendiri dan ia telah menjalaninya.

3) Bahwa aspirasi rakyat adalah kehendak jaman yang tak terbantah dan tidak dapat dibendung apalagi sampai dihalang-halangi oleh suatu norma yang pada hakikatnya tidak sejalan dengan pasal 28 I ayat (2) UUD 1945, sehingga perlu dilakukan upaya perbaikan aturan seperti apa yang dikehendaki oleh konstitusi dan semangat demokrasi.

4) Bahwa dengan demikian adanya pasal-pasal a quo selain telah mengenyampingkan rakyat juga bukanlah sebuah UU/ pembatasan yang adil, yang dapat menjamin pengakuan dan penghormatan atas hak asasi manusia, nilai-nilai agama dan ketertiban umum dalam suatu masyarakat demokratis sebagaimana yang diperintahkan UUD 1945, khususnya pasal $28 \mathrm{~J}$ ayat (2).

Kemudian permohonan mengajukan satu orang ahli yang bernama Dr. Mudzakir, SH.MH. telah memberi keterangan yang intinya sebagai berikut: Dalam memberikan argumen hukum Mahkamah Konstitusi menjelaskan yang intinya bahwa syarat tidak pernah dijatuhi pidana penjara berdasarkan putusan pengadilan yang telah mempunyai kekuatan hukum tetap karena melakukan tindak pidana yang diancam dengan pidana penjara 5 
tahun atau lebih sebagai salah satu syarat untuk menduduki jabatan publik yakni menuntut syarat kepercayaan masyarakat yang dinilai telah merupakan praktik yang diterima umum. Ada standar moral tertentu yang disyaratkan bagi setiap orang yang akan memangku jabatan-jabatan dalam pemerintahan yaitu tidak pernah dipidana. ${ }^{16}$

\section{Dasar Pertimbangan Putusan Mahkamah Konstitusi tentang Pencalonan Narapidana sebagai Anggota Legislatif}

Sebelum pada akhirnya Mahkamah Konstitusi mengeluarkan putusan No.4/PUU-VII/2009, sudah pasti mempunyai beberapa pertimbangan yang benar-benar matang dalam memutus suatu perkara. Dalam perkara ini Mahkamah Konstitusi mempunyai dasar pertimbangan yang dapat disimpulkan sebagai berikut:

a. Bahwa maksud dan tujuan permohonan adalah mengenai pasal pengujian konstitusional pasal 12 huruf g dan pasal 50 ayat (1) huruf g UU No.10 Tahun 2008 tentang pemilu anggota DPR, DPD, dan DPRD, serta pasal 58 huruf $f$ UU No.12 Tahun 2008 tentang Pemda.

b. Bahwa Mahkamah Konstitusi mempunyai kewenangan untuk mengadili pada tingkat pertama dan terakhir yang putusannya bersifat final untuk menguji Undang-Undang terhadap UUD, sebagaimana dinyatakan dalam pasal $24 \mathrm{C}$ ayat (1) UUD 1945 jo pasal 10 ayat (1) huruf a UU No. 24 Tahun 2008 tentang Mahkamah Konstitusi.

c. Bahwa sehingga Mahkamah berwenang untuk memeriksa, mengadili, dan memutus permohonan a quo.

d. Bahwa dalam kedudukan hukum (legal standing) pemohon menganggap hak dan kewenangan konstitusionalnya yang diberikan oleh UUD 1945 dirugikan oleh berlakunya suatu undang-undang. 
e. Bahwa Mahkamah Konstitusi bependapat pemohon memiliki kedudukan hukum (legal standing) untuk mengajukan permohonan pengujian pasal-pasal a quo terhadap UUD 1945.

f. Bahwa pemohon mendalilkan pasal a quo bertentangan dengan UUD 1945 sehingga harus dinyatakan tidak mempunyai kekuatan hukum yang mengikat.

g. Bahwa untuk memperkuat dalil-dalilnya, pemohon mengajukan alat bukti surat (bukti P-1 sampai dengan bukti P-9) juga mengajukan ahli Dr. Mudzakkir, SH.,MH. yang memberikan keterangan di sidang pleno pada tanggal 10 Maret 2009.

h. Bahwa dalam putusan No.14-17/ PUU-V/2007 tanggal 11 Desember 2007, mahkamah dalam amar putusannya telah telah menolak pengujian pasal 58 huruf $\mathrm{f}$ UU No. 32 Tahun 2004 tentang pemda, pasal 6 huruf E UU No 23 Tahun 2003 tentang pemilu presiden dan wakil presiden, pasal 18 ayat (1) huruf d UU MK, pasal 7 ayat (2) huruf d UU No. 5 Tahun 2004 tentang MA, dan pasal 13 huruf g No. 16 Tahun 2006 tentang badan pemeriksa keuangan.

\section{Posisi Yuridis Pasal 12 huruf g dan Pasal 50 Ayat (1) Huruf g UU Pemilu dan Pasal 58 Huruf $f$ UU Pemda.}

Belum lama berselang Mahkamah Konstitusi telah menerbitkan putusan tentang permohonan judicial review (uji materi) atas beberapa pasal dalam UU No. 10 Tahun 2008 tentang Pemilu dan UU No. 12 Tahun 2008 tentang pemda yang diduga bertentangan dengan UUD 1945, yang diajukan oleh Robertus Aji asal Lahat, Palembang, Sumatera Selatan.

Diantara keputusan itu adalah batalnya pasal 12 huruf g dan pasal 50 ayat (1) huruf g UU No. 10 Tahun 2008 dan pasal 58 huruf f UU No. 12 Tahun 2008, yakni norma hukum yang berbunyi: “tidak pernah dipidana penjara berdasarkan putusan pengadilan yang telah mempunyai kekuatan hukum tetap karena melakukan 
tindak pidana yang diancam dengan pidana penjara 5 (lima) Tahun atau lebih." Bertentangan dengan UUD 1945 secara bersyarat (conditionally unconstitutional), serta pasal-pasal a quo tidak mempunyai kekuatan hukum yang mengikat sepanjang tidak memenuhi syarat-syarat. ${ }^{17}$

Keputusan tersebut berimplikasi pada posisi yuiridis pasal a quo. Pasal a quo mensyaratkan ada pertentangan dengan UUD sebab norma hukum yang dicantumkan dalam pasal-pasal a quo telah berbuat tidak adil, yakni telah mendiskriminasikan antara warga negara yang mantan narapidana dengan warga yang bukan mantan narapidana serta tidak memberikan kedudukan hukum yang sama dalam hukum dan pemerintahan. Dan inkonsisten dalam menetapkan persyaratan-persyaratan sehingga menimbulkan ketidakpastian hukum.

Dalam karya Sumali yang berjudul Reduksi Kekuasaan Eksekutif, Cappelleti menegaskan bahwa untuk mengaktualisasikan perlindungan terhadap kaidah-kaidah konstitusi, setidaknya terdapat dua cara yang lazim ditempuh yaitu: pengawalan secara politik dan pengawasan secara yuridis (judicial review). Kedua model pengawasan tersebut dilakukan dengan cara menilai atau menguji apakah suatu undang-undang yang ada bertentangan atau tidak dengan konstitusi. ${ }^{18}$ Dalam hal ini yang berhak atau yang berwenang menguji pasal-pasal a quo adalah Mahkamah Konstitusi yang tertuang dalam pasal $24 \mathrm{c}$ ayat (1) UUD 1945 jo pasal 10 ayat (1) UU No. 24 Tahun 2008 tentang Mahkamah Konstitusi, yakni "Mahkamah Konstitusi berwenang mengadili pada tingkat pertama dan terakhir yang putusannya bersifat final untuk menguji undang-undang terhadap UUD".

Mengenai kewenangan untuk menguji undang-undang terhadap UUD secara teoritik maupun praktek dikenal ada dua macam yaitu pengujian formal dan pengujian secara materiil.

\footnotetext{
${ }^{17}$ Putusan Mahkamah Konstitusi No.4/ PUU-VII/ 2009

${ }^{18}$ Sumali, Reduksi Kekuasaan Eksekutif Di Bidang Peraturan Pengganti UU, (Malang: UMM Press, 2003), 59
} 
Pengujian secara formal adalah untuk menilai apakah seuatu produk legislatif dibuat sesuai prosedural ataukah tidak. Serta apakah suatu kekuasaan berhak mengeluarkan suatu peraturan tertentu. Sedangkan pengujian secara materiil adalah wewenang untuk menyelidiki dan menilai apakah peraturan perundangundangan bertentangan atau tidak dengan peraturan yang lebih tinggi. ${ }^{19}$

Dengan kewenangan tersebut MK berhak membatalkan pasal-pasal a quo sebab bertentangan dengan UUD 1945 dan karena tidak mempunyai kekuatan hukum yang mengikat lagi. Jadi Mahkamah memperbolehkan mantan narapidana mencalonkan diri untuk menduduki jabatan publik yang dipilih (DPR, DPD, DPRD, dan Kepala Daerah).

Dari putusan MK tersebut norma hukum baru telah terbentuk dan norma hukum yang bertentangan dengan UUD 1945 menjadi norma hukum yang tidak lagi bertentangan. Mahkamah Konstitusi memang tidak dapat melakukan pembentukan aturan hukum baru karena tidak mempunyai kewenangan legislasi, namun dapat menemukan norma hukum baru dengan putusannya. ${ }^{20}$ Hal ini telihat dalam pertimbangannya yang berbunyi:

"Meskipun Mahkamah Konstitusi berwenang menyatakan suatu norma hukum yang tercantum dalam suatu undang-undang inkonstitusional atau bertentangan dengan UUD 1945 dan karenanya tidak mempunyai kekuatan hukum yang mengikat, namun Mahkamah membuat rumusan baru suatu norma undangundang". (vide putusan MK No.4/PUU-VII/2009:79)

Putusan Mahkamah Konstitusi tersebut merupakan penemuan hukum. Menurut Sudikno Mertokusumo, penemuan hukum adalah proses pembentukan hukum oleh hakim atau aparat hukum lainnya yang ditugaskan untuk menetapkan

\footnotetext{
19 Fathurrahman, dkk, Memahami Keberadaan Mahkamah Konstitusi Indonesia, (Bandung: PT Citra Aditiya Bakti, 2004), $21-22$

${ }^{20}$ www.lampung.com.
} 
peraturan hukum umum pada peristiwa hukum konkrit. ${ }^{21}$ Menemukan hukum merupakan karya manusia dan ini berarti bahwa setiap penerapan hukum selalu didahului oleh seleksi subyektif, yakni mengenai peristiwa-peristiwa dan peraturanperaturan yang relevan.

Hasil penemuan hukum oleh hakim itu merupakan hukum karena mempunyai kekuatan sebagai hukum karena dituangkan dalam bentuk putusan. Disamping itu hasil penemuan hukum oleh hakim itu merupakan sumber hukum juga. ${ }^{22}$

Jadi putusan No.4/PUU-VII/2009 merupakan penemuan hukum dalam yudisial review oleh hakim Mahkamah Konstitusi. Yang keputusan tersebut berakibat pada posisi yuridis pasal 12 huruf g dan pasal 50 ayat (1) huruf g UU pemilu dan pasal 50 huruf $\mathrm{f}$ UU pemda, yakni tidak lagi mempunyai kekuatan hukum yang mengikat sebab pasal-pasal a quo bertentangan dengan UUD 1945 secara bersyarat (inconstitusional bersyarat) pasal tersebut tidak mempunyai kekuatan hukum yang mengikat sepanjang tidak memenuhi syarat-syarat tertentu.

\section{Mantan Narapidana Menduduki Jabatan Publik yang Dipilih (Elected Officials)}

Selain berimplikasi pada posisi yuridis pasal 12 huruf g dan pasal 50 ayat (1) huruf g UU pemilu dan pasal 58 huruf $\mathrm{f}$ UU pemda, pasca putusan MK No.4/PUU-VII/2009 juga berimplikasi pada aspek politik yaitu dibukanya kesempatan bagi mantan narapidana untuk menduduki elected officials (jabatan publik yang dipilih).

Dibukanya kesempatan kepada mantan narapidana dalam berpolitik berarti Mahkamah Konstitusi telah berbuat adil dan telah mengembalikan hak-haknya yang telah dirampas karena dulu pernah dipidana.

21 Sudikno Mertokusumo, Penemuan Hukum Sebuah Pengantar, (Yogyakarta: Liberty, 1996), 37

22 Ibid., 38 
Menurut Sudikno Mertokusumo, pada hakikatnya sanksi bertujuan untuk memulihkan keseimbangan tatanan masyarakat yang telah terganggu oleh pelanggaran-pelanggaran kaedah dalam keadaan semula. ${ }^{23}$

Sehingga apabila setiap warga negara yang telah menjalani hukuman (pidana penjara) berdasarkan putusan pengadilan yang telah berkekuatan hukum tetap, dipersamakan telah mengembalikan tatanan dan keseimbangan masyarakat dalam keadaan semula. Dengan demikian warga yang pernah menjalani hukuman itu sama artinya dengan warga negara lainnya yang dilahirkan dalam keadaan bersih, bebas, berharkat, dan bermartabat serta sederajat di mata hukum.

Dalam konsep pemasyarakatan terdapat tujuan luhur yaitu mendidik para narapidana yang selama ini dianggap tersesat, agar menjadi orang yang berguna bagi bangsa dan negara. ${ }^{24}$ Dengan tujuan tersebut diharapkan orang yang telah menjalani hukuman dapat menjadi orang yang berguna serta aktif berperan dalam pembangunan, serta dapat hidup secara wajar sebagai warga negara yang baik dan bertanggung jawab. Untuk mewujudkan tujuan tersebut, narapidana tidak hanya dididik dan diberi keterampilan saja tetapi juga dibimbing untuk dimasyarakatkan. Apabila tujuan pemidanaan adalah pemasyarakatan, maka mantan narapidana harus dapat diterima dalam masyarakat, harus dapat hidup berdampingan dalam masyarakat.

Dalam putusannya Mahkamah Konstitusi menyatakan bahwa pasal-pasal a quo yang tercantum dalam UU No. 10/ 2008 dan UU No. 12/ 2008 bertentangan dengan UUD 1945 secara bersyarat (conditionally unconstitusional) dan tidak mempunyai kekuatan hukum yang mangikat sepanjang tidak memenuhi syarat-syarat tertentu. ${ }^{25}$ Dengan putusan MK No.4/PUU-VII/2009 berarti telah dibuka lebar kesempatan bagi mantan narapidana untuk

\footnotetext{
${ }^{23}$ Sudikno Mertokusumo, Mengenal Hukum Suatu Pengantar, (Yogyakarta: Liberty, 1991), 10

${ }^{24}$ Made Darma Weda, Kriminologi, (Jakarta: PT. Raja Grafindo Persada, 1996), I 1

25 Putusan MK No. 4/ PUU-VII/ 2009, 83-84.
} 
menduduki jabatan publik yang dipilih (elected officials). Inilah implikasi politik yang terkandung dalam putusan Mahkamah Konstitusi No.4/PUU-VII/2009. Keputusan MK tersebut berimplikasi positif yang menggembirakan publik sebab hak mantan narapidana telah dikembalikan, yakni tidak adanya diskriminasi, adanya pengakuan dan penghormatan atas hak asasi manusia, nilai-nilai agama dan ketertiban umum dalam suatu masyarakat demokrasi sebagaimana yang diperintahkan oleh UUD 1945.

\section{Analisis Fiqh Siyasah terhadap Pencalonan Mantan Narapidana sebagai Anggota Legislatif, DPD dan Kepala Daerah}

Putusan MK No. 4 /PUU-VII/2009 tentang diperbolehkannya mantan narapidana untuk mencalonkan diri sebagai anggota legislatif, DPD dan Kepala Daerah ternyata tidak begitu saja diterima oleh masyarakat. Sebab mereka menganggap bahwa seorang mantan yang pernah dipenjara adalah seorang yang dicacat moral dan identik dengan berbuat yang tidak baik. Jadi masyarakat memberikan cap atau lebel yang kurang baik terhadap mantan narapidana.

Banyak masyarakat yang berargumentasi bahwa untuk menjadi pegawai saja diperlukan surat keterangan berkelakuan baik dari kepolisian, apalagi untuk menduduki jabatan pemerintahan; apa jadinya jika sebuah pemerintahan dipegang oleh orang-orang yang tidak mempunyai moral yang baik, pasti akan sering berbuat hal-hal yang merugikan rakyat. Argumentasi tersebut hanya melihat dari segi negatifnya tanpa mau melihat dari segi positifnya dari seorang mantan narapidana.

Dalam kopsep siyasah dusturiyah yang merupakan dari fiqh siyasah yang mencakup masalah perundang-undangan dan hak umat, di negara islam umat mencakup seluruh rakyat baik muslim, maupun kafir z\{immy, baik kaya maupun miskin, yang pejabat maupun bukan. Mereka semuanya mempunyai hak-hak yang harus dijamin, dihormati, dan dilindungi oleh pemerintah. 
Termasuk hak-hak mantan narapidana yang sudah bertaubat dia juga berhak untuk mendapatkan perlindungan, jaminan atas hakhak asasi dari pemerintah. Dari perspektif inilah penulis akan mencoba mengkaji tentang pencalonan mantan narapidana sebagai anggota legislatif, DPD dan kepala daerah dari segi fiqh siyasah.

Seorang mantan narapidana adalah orang yang dulu pernah melakukan perbuatan kejahatan/tinkadan kriminal dan telah menjalani hukuman pidana. Dalam islam orang yang pernah melakukan perbuatan tercela atau dosa itu dianggap sebagai orang cacat moral sehingga hak-haknya tidak bisa diperoleh secara penuh kecuali telah bertaubat, dan mengerjakan perbuatan baik sebagai penghapus dosa yang telah lalu.

Memang dalam menduduki jabatan pemerintah sebagai pemimpin (amir), wakil rakyat(ahl al-h\{alli wa al-'aqdi) dan jabatan yang lainnya dalam negara islam, para ahli fikih memprioritaskan kepada orang yang mempunyai kriteria yang bagus seperti, mampu, berilmu, berakhlaq baik, berkualitas tinggi dan sebagainya dengan tujuan dapat menjalankan pemerintahan sehingga tercapai suatu kemaslahatan bagi seluruh umat. Begitu pula undang-undang yang telah ditetapkan oleh pemerintah indonesia, juga bertujuan demikian.Dalam beberapa pasal disebutkan syarat-syarat menjadi anggota legislatif DPD dan kepala daerah. Yakni pasal $12 \mathrm{~h}$ uruf g, pasal 50 ayat 1 huruf g UU NO>.10 Tahun 2008 tentang pemilu legislatif dan pasal 58 huruf $f$ UU NO.12 tahun 2008 tentnag Pemda. Norma hukum dalam pasal tersebut berbunyi sebagai berikut:

"Tidak pernah dijatuhi pidana penjara berdasarkan putusan pengadilan yang mempunyai kekuatan hukum tetap karena melakukan tindak pidana yang diancam dengan pidana penjara lima tahun atau lebih."

Dari bunyi pasal tersebut terlihat bahwa untuk menjadi anggota legislatif, DPD dan kepala daerah, harus dari orang yang benar-bener bersih dari tindakan tercela. Sebab undang-undang tersebut bertujuan agar dapat diperoleh pemimpin yang 
berkualitas tinngi, sehingga diperoleh track record yang tidak tercela.akan tetapi hal tersebut apakah sudah adil, jika seorang mantan narapidana mempunyai kemampuan memimpin untuk mengatur pemerintahan, apalagi dia sudah menjalani hukuman dan telah membayar semua atas perbuatan jahat yang pernah dilakukan dulu.

Dalam siyasah dusturiyah yang merupakan bagian figh dusturiyah yang membahas masalah perundang-undangan negara agar sejalan dengan nilai-nilai syari'at. Sebab tujuan dibuatnya peraturan perundang-undangan adalah untuk mewujudkan kemaslahatan manusia dan untuk memenuhi kebutuhan manusia. Jika peraturan perundang-undangan tersebut tidak sejalan dengan tujuan syari'at islam dalam arti telah merugikan hak-hak rakyat. Maka dalam hal ini yang berwenang untuk memutus masalah ini adalah lembaga yudikatif atau sultah al-Qadaiyah yang terdiri dari tiga lembaga peradilan yakni disebut dengan wilayah al-qada', wilayah al-hisbah dan wilayah al-mazalim. Ketiga lembaga peradilan tersebut mempunyai kewenangan masing-masing dalam memutuskan suatu perkara. Dan yang berwenang memutus dalam masalah ini yakni mengenai perkara yang tejadi antara rakyat dan negara adalah wilayah al-mazalim.

Menurut al-mawardi tujuan didirikannya wilayah al-mazalim adalah untuk memelihara hak-hak rakyat atau umat dari perbuatan zalim para penguasa, pejabat dan keluarganya, untuk mengembalikan hak-hak rakyat yang telah diambil oleh mereka dan untuk menyelesaikan perkara antara penguasa dan warga negara. ${ }^{26}$

Islam memerintahkan dalam menetapkan hukum diantara manusia haruslah berlaku adil, karena kedudukan berlaku adil adalah sebagai prinsip konstitusional dan sebagai poros politik 
keagamaan. Sebagaimana dituangkan dalam Surat An-Nisa' ayat 58. Allah berfirman: ${ }^{27}$

"Sesungguhnya Allah menyuruh kamu menyampaikan amanat kepada yang berhak menerimanya, dan (menyuruh kamu) apabila menetapkan hukum di antara manusia supaya kamu menetapkan dengan adil. Sesungguhnya Allah memberi pengajaran yang sebaik-baiknya kepadamu. Sesungguhnya Allah adalah Maha mendengar lagi Maha Melihat".( Surat An-Nisa' ayat 58)

Ayat di atas menjelaskan bahwa Allah memerintahkan untuk menunaikan amanat secara sempurna serta ditunaikan kepada pemiliknya atau yang berhak menerimanya, baik amanah yang menyangkut hak-hak Allah atas hambanya seperti shalat, zakat, puasa, dan sebagainya, maupun amanah manusia. Selain itu Allah menyuruh kamu ketika menetapkan hukum diantara manusia, baik yang berselisih dengan manusia lain atau tanpa perselisihan. Maka kalau menetapkan putusan dengan adil sesuai dengan apa yang diajarkan oleh Allah SWT, yaitu tidak memihak kecuali kepada keberatan dan tidak pula menjatuhkan sanksi kecuali kepada yang melanggar, tidak mengadilinya walaupun itu berlawanan dan tidak memihak kepada semaumu. ${ }^{28}$ Hal ini berarti bahwa perintah berbuat adil ditujukan kepada manusia secara keseluruhan. Dengan demikian baik amanah maupun keadilan harus ditunaikan dan ditegakkan tanpa membeda-bedakan agama, keturunan, ras ataupun kedudukan dalam masyarakat.

Ini berarti Islam tidak membedakan dalam hal kedudukan, ras, agama maupun status sosialnya dalam masyarakat. Sehingga mantan narapidana maupun bukan mantan narapidana mempunyai hak-hak yang sama dalam pandangan Islam apabila ia benar-benar telah bertaubat.

27 Departemen Agama Rl, Al-Qur'an dan Terjemahannya, (Jakarta: Yayasan Penyelenggaraan Penterjemahan Al Qur'an, 2005)

${ }^{28}$ M. Quraisy Shihab, Tafsir Al-Misbah, Pesan, Kesan dan Keserasian Al-Qur'an, Vol. 2, (Jakarta: Lentera Hati, 2000), 198 
Ketika seorang yang pernah melakukan kejahatan kemudian ia bertaubat sungguh-sungguh yakni dengan tidak mengulang kembali kejahatan yang dulu pernah diperbuatnya, maka sesungguhnya kebaikan itu dapat menghapus dosa.Sebagaimana Ibnu Mas'ud menceritakan hadis nabi bahwa orang yang pernah melakukan dosa maka dapat dihapuskan dengan melakukan kebaikan yakni dengan menjalankan sholat pada pagi dan sore serta sebagian wakatu malam. ${ }^{29}$

Dari penjelasan di atas dapat dipetik satu hal bahwa putusan MK No. 4/PUU-VII/2009 yang membolehkan mantan narapidana sebagai anggota legislatif, DPD dan kepala daerah dengan syaratsyarat tertentu, telah mengembalikan hak-hak rakyat yakni hak seorang mantan narapidanan untuk ikut berpartisipasi dalam politik dan hak yang sama dihadapan hukum. Sebab dia sudah bertaubat dan telah membayar semua kesalahannya di masa lalu yaitu dengan dipidana penjara.

Dengan demikian seorang mantan narapidana boleh memjadi anggota legislatif, DPD dan kepala daerah apabila ia telah bertaubat seperti apa yang disyaratkan oleh Mahkamah Konstitusi yakni berlaku untuk jabatan publik yang dipilih (elected officials), berlaku terbatas jangka waktunya hanya selama 5 (lima) Tahun sejak terpidana selesai menjalani hukumannya, dikecualikan bagi mantan terpidana yang secara terbuka dan jujur mengemukakan kepada publik bahwa yang bersangkutan mantan terpidana, dan bukan sebagai pelaku kejahatan yang berulang-ulang.Dan tidak diberi wewenang pada jabatan yang membutuhkan kepercayaan yang tinggi dari masyarakat seprti jabatan Hakim, bagian keuangan negara dan sebagainya.Hal ini telah sesuai dengan syari'at Islam.

${ }^{29}$ Muhammad Fuad Abdul Baqi, al-Lu'lu' wal Marjan, (Surabaya, PT Bina IImu, 2006), 1072 


\section{Analisis terhadap Dasar Hukum Putusan MK No.4/PUU- VII/2009}

Dengan munculnya putusan MK No.4/PUU-VII/2009, hal tersebut disebabkan atas permohonan yang diajukan oleh Robertus Aji calon legislatif untuk DPRD kabupaten Lahat, Sumatera Selatan dan PDI Perjuangan yang gagal karena terganjal kasus pidana. Dia menyatakan bahwa dengan adanya ketentuan pasal 12 huruf g dan pasal 50 ayat (1) huruf g UU No.10/ 2008 tentang pemilu legislatif dan pasal 58 huruf f UU No.12/ 2008 tentang Pemda, telah berlaku tidak adil padanya. Padahal secara potensial sebagaimana dijamin oleh UUD 1945 pasal 27 ayat (1), pasal 28c ayat (2), pasal 28d ayat (1) dan (3).

Keputusan MK tentang diperbolehkannya mantan narapidana untuk mencalonkan diri sebagai pejabat publik (DPR, DPD, DPRD, Kepala Daerah) ternyata mengundanag kontroversi di kalangan masyarakat Indonesia. Mulai dari orang awam sampai dengan orang ahli hukum dan politik. Berbagai argumen tentang putusan MK tersebut muncul di berbagai media massa baik elektronik maupun media cetak.

Selanjutnya penulis akan menganalisa tentang dasar hukum yang digunakan Mahkamah Konstitusi dalam memutuskan perkara tersebut. Mahkamah Konstitusi dalam memutuskan perkara No.4/PUU-VII/2009 dilakukan dengan proses yang panjang dan melelahkan. Keputusan yang akhirnya dijatuhkan oleh MK yang didasarkan pada UUD 1945 yakni pasal 27 (1), pasal 28c (1), pasal 28d (1) dan (3), Berdasarkan dasar-dasar hukum diatas, akhirnya Mahkamah Konstitusi menyatakan bahwa norma hukum yang berbunyi:

"tidak pernah dijatuhi pidana penjara berdasarkan putusan pengadilan yang mempunyai kekuatan hukum tetap karena melakukan tindak pidana yang diancam pidana penjara selama 5 Tahun/lebih"

Yang terdapat dalam pasal 12 huruf g dan pasal 50 (1) huruf g UU No. 10/2008 tentang pemilu legislatif, pasal 58 huruf f UU No. 12/2008 tentang Pemda bertentangan dengan UUD 1945. Dan tidak 
mempunyai kekuatan hukum yang mengikat sepanjang tidak memenuhi syarat.

Sebab jika norma hukum yang terkandung dalam pasal a quo tetap diberlakukan tanpa syarat-syarat tertentu dapat menegasi atau mengingkari prinsip penamaan kedudukan dalam hukum dan pemerintahan serta hak melanggar hak seorang warga negara atas perlakuan, jaminan, perlindungan dan kepastian hukum yang adil, serta perlakuan hukum yang sama dihadapan hukum dan hak memperoleh kesempatan yang sama dalam pemerintahan. Sebagaimana dijamin oleh UUD 1945 terutama pasal-pasal sebagai berikut: Pasal 27 ayat (1), Pasal 28c ayat (2), Pasal 28d ayat (1) dan Pasal 28d ayat (3).

Dari penjelasan pasal-pasal di atas jika diteliti secara seksama memang undang-undang pemilu legislatif dan undang-undang Pemda bertentangan dengan UUD 1945. Dengan dilarangnya seorang mantan narapidana menjadi pejabat publik (DPR, DPD, DPRD dan Kepala Daerah) berarti sama dengan yang dianjurkan dalam Islam karena Islam tidak pernah membeda-bedakan umat manusia dalam hal kedudukannya sebagai apa atau yan-g lainnya khususnya dalam pemerintahan. Hal tersebut jelas disebutkan dalam al-Qur' an Surat an-Nur ayat $55: 30$

"Dan Allah Telah berjanji kepada orang-orang yang beriman di antara kamu dan mengerjakan amal-amal yang saleh bahwa dia sungguhsungguh akan menjadikan mereka berkuasa dimuka bumi, sebagaimana dia Telah menjadikan orang-orang sebelum mereka berkuasa, dan sungguh dia akan meneguhkan bagi mereka agama yang Telah diridhaiNya untuk mereka, dan dia benar-benar akan menukar (keadaan) mereka, sesudah mereka dalam ketakutan menjadi aman sentausa. mereka tetap menyembahku-Ku dengan tiada mempersekutukan sesuatu apapun dengan Aku. dan barangsiapa yang (tetap) kafir sesudah (janji) itu, Maka mereka Itulah orang-orang yang fasik". (Surat an-Nur ayat 55)

${ }^{30}$ Departemen Agama RI, Al-Qur'an dan Terjemahannya. 
Dalam ayat di atas tidak disebutkan orang yang seperti apa dengan mempunyai kriteria seperti apa yang menjadi khalifah di bumi. Dalam hal ini islam tidak membeda-bedakan seluruh umat manusia.

Dengan demikian apa yang telah diputuskan oleh MK telah sesuai dengan apa yang telah diajarkan oleh islam.Sebab putusan MK yang memperbolehkan mantan narapidana untuk menduduki jabatan anggota legislatif, DPD dan kepala daerah dengan syaratsyarat tidak melakukan kejahatan berulang-ulang atau telah bertaubat.Sehingga dengan syarat-syarat tersebut dapat menghilangkan kekawatiran masyarakat terhadap mantan narapidana.

Atas beberapa dasar petrimbangan yang didasarkan pada dalil-dalil pemohon, alat bukti surat, keterangan ahli yang diajukan,keterangan pemerintah dan pihak terkait. Akhirnya MK memutuskan bahwa pasal a quo bertentangan dengan UUD secara bersyarat.

Bila seorang yang telah menjalani penjara atau pemasyarakatan masih tidak dapat disamakan dengan orang yang belum pernah dipenjara, maka itu merupakan pengakuan sistem pemasyarakatan indonesia yang gagal. Artinya proses pemasyarakatan selama ini yang dilakukan oleh negara tidak berhasil mengembalikan kedudukan mantan narapidana sebagai anggota masyarakat yang normal.

Jadi putusan MK yang memperbolehkan mantan narapidana untuk menduduki jabatan legislatif, DPD dan kepala daerah dengan syarat-syarat tertentu telah sesuai dengan apa yang diperintahkan oleh Islam.

\section{Analisis terhadap Implikasi Putusan MK NO. 4/PUU-VII/2009}

Dalam hal ini penulis akan mengemukakan analisis terhadap implikasi putusan MK No.4/PUU-VII/2009. Setelah putusan MK tersebut dibacakan dalam sidang pleno terbuka untuk umum pada tanggal 24 Maret 2009. Pada saat itulah pasal 12 huruf g dan pasal

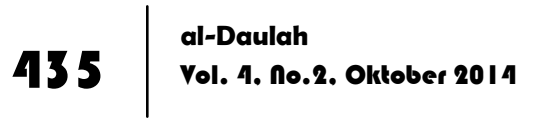


50 ayat (1) huruf g UU No. 10 Tahun 2008 tentang pemilu legislatif dan pasal 58 huruf f UU No. 12/ 2008 tentang Pemda dinyatakan inkonstitusional bersyarat dan tidak mempunyai kekuatan hukum yang mengikat.

Dari keputusan yang telah ditetapkan oleh MK tersebut berimplikasi pada posisi yuridis pasal-pasal a quo dan berimplikasi pada aspek politik yaitu membuka kesempatan bagi mantan narapidana untuk dapat menduduki jabatan publik yang dipilih (elected offials), dengan demikian hak politik mantan narapidana telah dikembalikan.

Mengenai implikasi pada posisi yuridis pasal 12 huruf g dan pasal 50 ayat (1) huruf g UU No. 10/ 2008 dan pasal 58 huruf $f$ UU No. 12/ 2008. Pasca putusan MK No.4/PUU-VII/2009, pasal-pasal a quo tidak berlaku lagi sebab tidak mempunyai kekuatan hukum yang mengikat sepanjang tidak memenuhi syarat-syarat yaitu tidak berlaku untuk jabatan publik yang dipilih (elected offials), berlaku terbatas jangka waktunya hanya selama 5 (lima) Tahun sejak terpidana selesai menjalani hukumannya. Dikecualikan bagi mantan terpidana yang secara terbuka dan jujur mengemukakan kepada publik bahwa yang bersangkutan mantan narapidana dan bukan sebagai pelaku kejahatan yang berulang-ulang.

Mahkamah berkesimpulan, norma yang diajukan tersebut jika diberlakukan tanpa syarat-syarat dapat menegasi prinsip persamaan dan kedudukan dalam hukum dan pemerintahan. Serta melanggar hak warga negara untuk memperoleh kesempatan yang sama dalam pemerintahan yang pada hakikatnya merupakan moralitas hukum dan moralitas konstitusi.

Mengingat kekhususan-kekhususan karakter jabatan-jabatan publik tertentu menyebabkan tidak semua jabatan publik dapat ditentukan persyaratannya dengan rumusan norma yang bersifat umum, sehingga perlu pembedaan persyaratan. Yaitu antara jabatan publik yang dipilih (elected officials) dan jabatan publik yang diangkat (appointed officials). Selain itu, mahkamah menerangkan dalam merumuskan persyaratan bagi jabatan publik 
yang sama karakternya juga harus dengan persyaratan yang sama agar jangan sampai terjadi ketidakpastian hukum.

Dari pertimbangan mahkamah diatas jelas dapat dilihat bahwa pasal aquo dalam UU Pemilu Legislatif dan UU Pemda menunjukkan ketidakkonsistenan para pembentuk Undangundang dalam menetapkan persyaratan-persyaratan untuk menjadi pejabat publik yang akhirnya mengakhibatkan ketidakadilan dan ketidakpastian hukum.

Setelah dikaji lebih jauh ternyata posisi yuridis pasal-pasal aquo yang tercantum dalam Undang-undang pemilu legislatif dan Undang-undang Pemda, memang tidak layak untuk diberlakukan lagi sebab pasal-pasal a quo bertentangan dengan apa yang telah dijamin oleh UUD 1945, khususnya pasal 27 (1), pasal 28C (2), pasal 28D (1) dan (3).

Putusan Mahkamah yang telah penulis paparkan pada bab III merupakan pembentukan hukum baru yaitu dengan dikembalikannya hak-hak mantan narapidanan. Norma hukum baru ini terbentuk dari norma hukum yang bertentangan dengan UUD 1945 menjadi norma hukum yang tidak lagi bertentangan dengan UUD 1945. Walaupun Mahkamah berwenang membentuk aturan-aturan hukum baru dengan putusannya, akan tetapi tidak berwenang membentuk aturan-aturan hukum baru. Ini seharusnya dijadikan dasar bagi pembentuk undang-undang untuk tidak menutup kesempatan bagi mantan narapidana untuk mencalonkan diri menjadi pejabat publik.

Dari uraian di atas terlihat bahwa putusan MK No. 4/PUUVII/2009 berimplikasi pada posisi yuridis pasal 12 huruf g dan pasal 50 (1) huruf UU No. 10/2008 dan pasal 58 huruf f UU No.12/2008, yakni pasal-pasal a quo bertentangan dengan UUD 1945 secara bersyarat karenanya tidak mempunyai kekuatan hukum yang mengikat sepanjang tidak memenuhi syarat-syarat tertentu. Jadi pasal tersebut tidak dapat diberlakukan lagi tanpa memenuhi syarat-syarat tertentu. 
Implikasi yang lain pasca putusan MK No. 4/PUU-VII/2009, yakni pada aspek politik, di mana MK membuka kesempatan bagi mantan narapidana untuk dapat menduduki jabatan publik yang dipilih (elected officials).

Menurut Mahkamah Konstitusi, norma hukum juga tidak bisa dilepaskan dari moralitas yang mendasarinya yakni keadilan. Mahkamah Konstitusi mempertimbangkan pemohonan dengan melihat ke belakang mengenai putusan MK sebelumnya terkait dengan norma hukum persyaratan a quo dibandingkan dengan amnesti terhadap mereka yang terlibat perjuangan rakyat semesta (PRRI - Permesta), Gerakan Aceh Merdeka, dan keterlibatan langsung ataupun tidak langsung dengan G 30 S/PKI untuk menjadi calon DPR, DPD dan DPRD dalam putusan MK NO. 11 17 PUU - 1/2003 tanggal 24 februari 2004.

Atas dasar pertimbangan tersebutlah Mahkamah Konstitusi memutuskan bahwa pasal-pasal yang tercantum dalam UU Pemilu Legislatif dan UU Pemda bertentangan dengan UUD 1945 dan karenanya tidak mempunyai kekuatan hukum yang mengikat. Ini berarti Mahkamah Konstitusi telah membuka lebar kesempatan bagi mantan narapidana untuk dapat menduduki jabatan publik yang dipilih. Dengan kata lain Mahkamah Konstitusi sudah menegakkan keadilan dan menghapus diskriminasi antar sesama rakyat Indonesia dalam pemerintahan.

Setelah putusan No. 4/PUU-VII/2009, diharapkan tidak ada lagi stigma yang buruk terhadap mentan narapidana, tidak lagi dicurigai, diasingkan, dan dapat diterima dalam masyarakat.

Sebab tujuan pemidanaan adalah membebaskan narapidana secara mental dan spiritual. Dengan tujuan pembebasan tersebut, narapidana seolah-olah mengalami kelahiran kembali secara mental dan spiritual dan akan melepaskan segala cara berfikir, kebiasaan, dan gaya kehidupan yang lama. Pemulihan kembali hak-hak dan kebebasan tersebut ditujukan agar orang yang telah menjalani hukuman dapat aktif berperan dalam pembangunan 
dan dapat hidup secara wajar sebagai warga negara yang baik dan bertanggungjawab.

Secara teoritis, seorang pelaku kejahatan yang telah dijatuhi pidana dan menyelesaikan masa pidananya dengan baik, maka orang tersebut lepas dari segala kesalahan-kesalahan yang telah dilakukan telah dibayar dengan pemidanaan.

Kalau masih terjadi perlakuan diskriminatif terhadap mantan narapidana maka tujuan pemidanaan tidak tercapai atau gagal. Hal ini terlihat pada pasal 12 huruf g dan pasal 50 (1) huruf g UU No. 10/2008 dan pasal 58 huruf $f$ UU No. 12/2008 yang telah dibuat oleh para pembentuk Undang-undang yang masih mendiskriminasikan mantan napi dengan yang bukan, dan menganggap bahwa mantan narapidana adalah orang yang harus dicurigai tercela, cacat moralnya dan tidak pantas menduduki jabatan publik yang dipilih (DPR, DPD, DPRD, Kepala Daerah maupun Presiden).

Dari uraian di atas penulis berpendapat bahwa pasca putusan MK No.4/PUU-VII/2009 mengandung implikasi positif dan cukup menggembirakan publik. Implikasi tersebut adalah mengenai posisi yuridis pasal 12 huruf g dan pasal 50 ayat (1) huruf g UU No. 10/ 2008 dan pasal 58 huruf f UU No. 12/ 2008, yakni pasalpasal a quo dinyatakan bertentangan dengan UUD 1945 secara bersyarat dan karenanya tidak mempunyai kekuatan hukum yang mengikat sepanjang tidak memenuhi syarat-syarat tertentu. Selain itu juga berimplikasi pada aspek politik yakni putusan MK telah membuka kesempatan bagi mantan narapidana untuk dapat menduduki jabatan publik yang dipilih (elected officials).

Dengan kedua implikasi positif tersebut, maka hak-hak konstitusional mantan narapidana sebagai warga negara atas perlakuan, jaminan, perlindungan dan kepastian hukum dan hak memperoleh kesempatan yang sama dalam pemerintahan sebagaimana dijamin dalam UUD 1945 khususnya pasal 27 (1), pasal 28c (2), pasal 28D (1) dan (3), telah kembali seperti dengan warga negara lainnya. Artinya tidak ada lagi diskriminasi diantara 
warga negara mantan narapidana dengan warga negara yang bukan mantan narapidana.

\section{Penutup}

Setelah mengkaji berbagai persoalan yang terkait dengan putusan Mahkamah Konstitusi No.4/PUU-VII/2009 tentang pencalonan mantan narapidana sebagai anggota legislatif, DPD dan Kepala Daerah, ada beberapa kesimpulan yang dapat ditarik di sini adalah:

Putusan MK No.4/PUU-VII/2009 yang menyatakan mantan narapidana boleh mencalonkan sebagai anggota legislatif, DPD dan kepala daerah, asalkan memenuhi syarat-syarat tertentu, ada 4 (empat) syarat. Putusan MK tersebut terkait dengan permohonan pengujian terhadap pasal 12 huruf g, pasal 50 ayat 1 huruf g UU No.1 tahun 2008 tentang pemilu legislatif dan pasal 58 huruf f UU No.12 tahun 2008 tentang Pemda, yang merupakan norma hukum yang inkonstitusional bersyarat. Mahkamah Konstitusi memperbolehkan mantan narapidana untuk mencalonkan sebagai anggota legislatif, DPD dan kepala daerah dengan syarat tertentu, dengan dasar pertimbangan bahwa Mahkamah Konstitusi mempunyai wewenang untuk menguji pasal-pasal tersebut, pemohon mempunyai kedudukan hukum (legal standing) dan pada pokok dalil-dalil permohonan pemohon.

Pasca putusan MK No.4/PUU-VII/2009 berimplikasi pada posisi yuridis pasal 12 huruf g dan pasal 50 ayat (1) huruf g UU No. 10 tahun 2008 dan pasal 58 huruf g UU No. 12 tahun 2008, dan berimplikasi pada aspek politik yakni membuka kesempatan kepada mantan narapidana menduduki jabatan publik yang dipilih (elected officials).

Berdasarkan kajian fiqh siyasah Putusan MK No.4/PUUVII/2009 yang memperbolehkan mantan narapidana sebagai anggota legislatif, DPD dan kepala daerah adalah sejalan dengan konsep siyasah dusturiyah yang mencakup hak-hak umat. Sebab 
mantan narapidana juga termasuk umat dalam negara Islam yang harus dilindungi hak-haknya, apabila bertaubat.

\section{Daftar Pustaka}

Aliyanto (Ketua P2KD). Wawancara, Sampang, 25 Mei 2012.

Azhar, Ipong S. Benarkah PPK Mandul: Pemilu, Parpol dan DPR Masa Orde Baru. Yogyakarta: Bigraf Pub., 1997.

Baqi, Muhammad Fuad Abdul. al-Lu'lu' wal Marjan. Surabaya, PT Bina Ilmu, 2006.

Budiardjo, Miriam. Demokrasi di Indonesia. Jakarta: Gramedia Pustaka Utama, 1996. . Dasar-Dasar Ilmu Politik. Jakarta: Gramedia Pustaka Utama, 2004.

Dahlan, Abdul Aziz. Ensiklopedi Hukum Islam. Jakarta: PT. Ichtiar Baru Van Hoeve, 1988.

Departemen Agama RI. Al-Qur'an dan Terjemahannya. Jakarta:

Yayasan Penyelenggaraan Penterjemahan Al Qur'an, 2005.

Fathurrahman, dkk. Memahami Keberadaan Mahkamah Konstitusi Indonesia. Bandung: PT Citra Aditiya Bakti, 2004.

http://mediaindonesia.com. Selasa, 24 Maret 2009, "Mantan Narapidana Jadi Caleg"

Kompas, Rabu 25 Maret 2009.

Marbun, BN. DPRD: Pertumbuhan, Masalah dan Masa Depannya. Jakarta: Erlangga, 1994.

Mertokusumo, Sudikno. Penemuan Hukum Sebuah Pengantar. Yogyakarta: Liberty, 1996. . Mengenal Hukum Suatu Pengantar. Yogyakarta: Liberty, 1991.

Pasal 1 ayat 2 UU RI No. 32 Tahun 2004 Tentang Pemda Putusan Mahkamah Konstitusi No.4/PUU-VII/2009

Shihab, M. Quraisy. Tafsir Al-Misbah, Pesan, Kesan dan Keserasian Al-Qur'an, Vol. 2. Jakarta: Lentera Hati, 2000. 
Sumali. Reduksi Kekuasaan Eksekutif Di Bidang Peraturan Pengganti UU. Malang: UMM Press, 2003.

Tutik, Titik Triwulan. Pokok-Pokok Hukum Tata Negara Pasca Amandemen UUD 1945. Jakarta: Prestasi Pustaka, 2006.

Weda, Made Darma. Kriminologi. Jakarta: PT. Raja Grafindo Persada, 1996.

www.hukumonline.com. Kamis, 7 September 2007, “Aspek Hukum"

www.lampung.com 